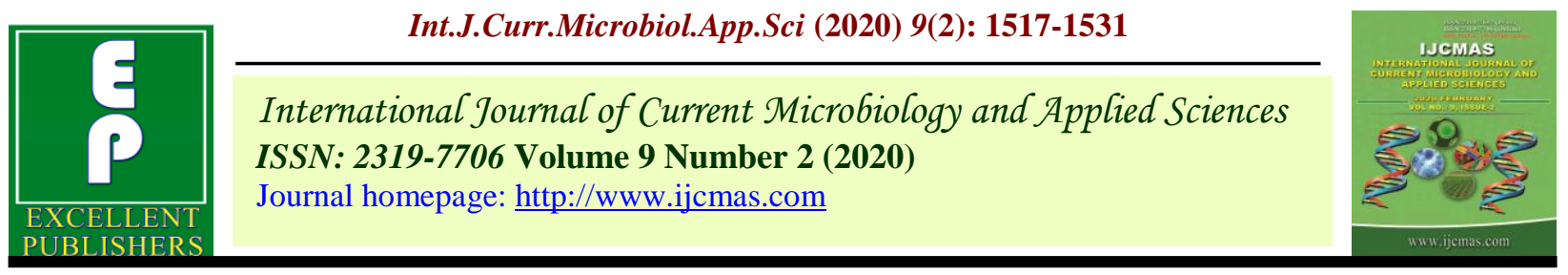

Original Research Article

https://doi.org/10.20546/ijcmas.2020.902.175

\title{
Population Dynamics of Major Insect-pests of Rice and their Natural Enemies and its Correlation with Weather Parameters in Central U.P
}

\author{
Devendra Singh*, R. S. Umrao, Kalpana Verma, Akshay Kumar and Vikrant \\ Department of Entomology, C. S. Azad University of Agriculture and Technology, \\ Kanpur (U.P.) India \\ *Corresponding author
}

\begin{tabular}{|c|}
\hline Keywords \\
\hline $\begin{array}{l}\text { Population } \\
\text { dynamics, Rice } \\
\text { insect-pests, Natural } \\
\text { enemies, Incidence } \\
\text { and Correlation }\end{array}$ \\
\hline Article Info \\
\hline $\begin{array}{l}\text { Accepted: } \\
08 \text { January } 2020 \\
\text { Available Online: } \\
10 \text { February } 2020\end{array}$ \\
\hline
\end{tabular}

A B S T R A C T

This paper discusses the population dynamics of rice insect-pests and its correlation with abiotic factor in Kanpur district of U.P. Incidence and abundance of rice insect-pests. Paddy crop was monitored during the seasons kharif, 2015 \& 2016. This investigation revealed that pest activity commenced from 34th Standard meteorological week (SMW) and continued to 49th std. week. Highest dead hearts (7.20 \& 6.90\%) of YSB (Scirpophaga incertulas) was found in the 39th std. week in both years. The 44th std. week registered the highest population of LF (Both, D\% \& No./5 sweeps) and GLH in kharif, 2015 \& 2016. Grass Hopper's population was its peak level (4.15) at 41st std. week in kharif, 2015 whereas it was found maximum in at 42nd std. week in kharif, 2016.The maximum population (20.50 \& 21.60) of GB was recorded at 43rd in both years kharif, 2015 and 2016, respectively. The 42nd std. week observed highest No. (4.95) of spider in kharif, 2015 while, it was maximum (5.75) at 39th std. week in kharif, 2016. Population of Dragon Fly was highest (1.50) at 39th std. week in kharif, 2015, whereas it was found maximum (2.25) at 41st std. week in kharif, 2016. The highest No. (3.35 \& 3.10) of Damsel Fly was recorded at 42nd std. week in both the experimental years kharif, 2015 \& 2016 respectively. The 44th std. week recorded the maximum No. (7.85) of LBB in kharif, 2015 while, it was observed its peak level (8.25) at 39th std. week in second year of experimental investigation kharif, 2016. Maximum temperature and relative humidity morning favours the YSB, LF, GH, GLH, GB, Spider, Drgn fly, Dmsl fly and LBB but rain fall and relative humidity evening was not ideal for insect-pests and natural enemies.

\section{Introduction}

Rice (Oryza sativa L.) is the most important single food crop of the world importance and staple food for nearly half of the world population. Rice belongs to genus Oryza of Gramineae family. Rice (Oryza sativa L.) is widely grown in tropical and subtropical regions (Singh et al., 2012). Rice is the second most important food crop of the world feeding over one half of its population, providing 20-80 per cent of the dietary energy in the average daily intake of people in Asia (Khush, 2005 and Babu et al., 2014). The rice plant is attacked by more than 100 species of insects and 20 of them can cause serious 
economic loss (Pathok, 1977). Paddy crop suffers maximum damage due to wide range of insects and non-insect-pests under different ecological conditions. Insects alone cause about $30-40 \%$ yield loss in rice every year by attacking almost all the aerial parts of the crop plants as well as root system in soil (Henrich et al., 1979; Dhaliwal et al., 1984; Prakash and Rao, 2003 and Anonymous, 2011). Among the various insect-pests damaging the rice crop stem borer, gall midge, grass hopper, brown plant hopper and leaf folder are major pest in India (Anonymous, 2003). In addition to pest species, rice ecosystem is replete with natural enemies like predators and parasitoids, which check the pest population (Kennedy and Storer, 2000).

The seasonal effects of weather and ongoing changes in climatic conditions will directly lead to modifications in dispersal and development of insect species. The changes in surrounding temperature regimes certainly involve alterations in development rates, voltinism and survival of insects and subsequently act upon size, density and genetic composition of populations, as well as on the extent of host plant exploitation (Kennedy and Storer, 2000 and Bale et al., 2002). The developmental success of insect herbivores also indirectly depends on climate, as environmental parameters impact on plant physiology. Insects and plants are exposed to complex interactions among changes in temperature, precipitation and, increased levels of $\mathrm{CO}$ and variations in nutrient availability. Milford and Dugdale (1990) reported temperature, day length, rainfall and relative humidity can be used as important components in forecasting and predicting the severity of insect-pests' population. Knowledge of population dynamics of insectpests and weather parameters are essential for developing sustainable crop protection strategies, for interpreting and forecasting the response of taxonomic groups to weathers patterns varying on a daily basis, seasonally, or as a long-term consequence of global climate change (Denholm et al., 2001). Information on population dynamics of insect-pests complex in relation to abiotic factors under Kanpur (Central U.P.) conditions is lacking. Information on the seasonal incidence and management of the insect-pests is very limited. Hence, considering the importance of insect-pests of rice an attempt has been made to study the population dynamics and its correlation with weather parameters.

\section{Materials and Methods}

For recording the population dynamics of insect-pests, the study was conducted at Students Instruction Farm of Chandra Shekhar Azad University of Agriculture and Technology Kanpur -208002 (U.P.) during Kharif, 2015 and 2016. The total experimental plot size measured 10x10m $\left(100 \mathrm{~m}^{2}\right)$. The seedlings were transplanted in the experimental plot with spacing $25 \mathrm{~cm}$ between plant to plant and $15 \mathrm{~cm}$ row to row. 21 days old seedlings of Pusa Basmati-1 rice variety were transplanted as per recommended agronomic practices, the nursery sown 21 days ago, in both the experimental years (Kharif, 2015 and 2016).

Method of Data Collection: Data collection was started after fifteen days of transplanting and subsequent at weekly intervals, using also sweeping method as per need. For insect-pests population, visuals counts of the numbers of insects/10 hills in plot were taken. Observations on incidence of insects were taken on hill basis. Ten plants (hill) were randomly selected from plot planted with Pusa Basmati-1 for recording incidence of insects. The observations continued till harvest of the crop. The observations were recorded at morning hours. 


\section{Results and Discussion}

To study the population dynamics of insectpests of paddy crop and their natural enemies and its correlation with weather parameters in Central U.P.:

Altogether five insect-pests viz., yellow stem borer, leaf folder, rice grass hopper, green leaf hopper and gundhi bug were observed attacking on rice crop in varying number at different stages of the crop and natural enemies viz. spider, dragon fly, damsel fly and lady bird beetle were also recorded at the time of investigation during Kharif, 2015 and 2016. During Kharif, 2015 and 2016, various insect-pests and natural enemies were recorded and presented in Table No.-1, 2, 3 and 4 and Fig-1\&2, Rice Leaf folder, Stem borer, Green leaf hopper and Ear head bug were the dominating insect-pests in rice ecosystem, which have been discussed as follows:

\section{Yellow stem borer}

The population of yellow stem borer was negatively correlated with minimum temperature, relative humidity (evening) and rainfall $(-0.02103,-0.00442$ and -0.05886 , respectively) (Table No.2). A positive correlation was with maximum temperature $(0.17806)$ and relative humidity morning (0.14476) during kharif, 2015. In kharif, 2016, the population was negatively correlated with relative humidity (E) and rainfall (-0.16378 and -0.24981$)$ and positive correlation was found with minimum temperature and relative humidity morning (0.06074 and 0.05000$)$ and correlation of this pest was positive with maximum temperature (0.14552) (Table No.4).

The maximum infestation of yellow stem borer (7.20 per cent in 2015 and 6.90 per cent in 2016) during $39^{\text {th }}$ std. week of both experimental years, thereafter dead hearts declined to 6.50 and 4.20 percent during 40 and 41 std. weeks, respectively in kharif, 2015, (Table No.1). In kharif, 2016 dead hearts declined to 4.89 and 3.65 percent during 40 and 41 std. weeks, respectively (Table No.3). Similar observations were also recorded by Israel and Rao (1961) and Singh, et al., (2013). Ayyanna and Hamidali (1970) also reported $S$. incertulas emergence started from second week of September, with a peak activity during the first week of October between temperatures of $30.60{ }^{0} \mathrm{C}$ and 21.60 ${ }^{0} \mathrm{C}$. The damage was negatively correlated with minimum temperature. The findings of present studies are in conformity with results of (Balasubramanian et al., 1982 and Lakka Vijaya Bhaskar, 1994).

\section{Leaf folder}

Results of correlation studies made on leaf folder population revealed that there were negative correlations with minimum temperature, relative humidity $(\mathrm{E})$ and rainfall $(-0.1665, \quad-0.00673, \quad$ and -0.08886 , respectively) while the damage by leaf folder showed positive correlations with maximum temperature (0.044247) and it was found positively correlated with relative humidity morning (0.206228) during kharif, 2015 (Table No.2). In kharif, 2016 the population of leaf folder was positively correlated with maximum temperature and relative humidity (M) (0.05298 and 0.007635), while negative correlation was found between leaf folder damage and minimum temperature $(-0.21408)$ and its population showed negative correlation with relative humidity (E) (0.43128 ) and a negative correlation was found with rainfall (-0.23067) (Table No.4).

The incidence of leaf folder revealed that the pest infestation was highest at $44^{\text {th }}$ std. week in the experimental year kharif, 2015 and 2016. Similar results were also observed by 
Kumar, et al., (1996) they recorded the infestation of rice leaf folder, $C$. medinalis Guen., varied from 1.4 to 33.2 per cent in rice from July to October. Singh et al., (2003) rice leaf folder, $C$. medinalis has gained major pest status now a days and caused severe yield losses. Mishra and Mandal, (2003) reported the similar research. Kumar et al., (2003) found that the peak activity leaf folder in the October during the Kharif, season. Alvi, et al., (2003) found that the activity of $C$. medinalis lasted from the second week of August to the second week of October during 2000, while it lasted from the last week of August to the second week of October during kharif, 2001. The leaf folder infestation on leaves was noticed that peak leaf infestation was maximum $(61.9 \%)$ at second week of October (Chhavi et al., 2015). Kumar et al., (2013) and Khan and Ramamurthy (2004) told in his research's result the rice leaf folder population were higher in the month of October, exhibiting peak activity in the first week, followed by September, they also reported that the maximum temperatures and relative humidity in the morning were highly significant and the minimum temperatures had negative impact on population build up. However, the RH in the morning had a positive impact on population build up.

The report of Khan, et al., (2004) also support the present investigation, results of correlation studies made on leaf folder population revealed that there were negative correlations with minimum temperature, relative humidity (evening) and rainfall $(-0.1665,-0.00673$, and -0.08886) while the damage by leaf folder showed positive correlations with maximum temperature (0.044247) and it was found positively significant with relative humidity morning (0.206228)

\section{Grass hopper}

The population of $\mathrm{GH}$ was negatively correlated with minimum temperature and rainfall (-0.00847 and -0.02458). It was positively correlated with relative humidity (E). There was a positive correlation found with maximum temperature and relative humidity [M] (0.189706 and 0.13911) during kharif, 2015, (Table No.2). In kharif, 2016, its population had positive correlation with maximum temperature (0.189256). While, a negative correlation was found with minimum temperature (-0.02299) and relative humidity (M). A negative correlation also was found with relative humidity (E) and rainfall (0.36752 and -0.33879 ) (Table No.4).

The data showed that the higher population $4.33,4.15$ and 3.96 per five sweep in $41^{\text {th }}$ std., $44^{\text {th }}$ std. and $39^{\text {th }}$ std. week, respectively in kharif, 2015, (Table No.1). During kharif, 2016 its population was highest $8.52,6.132$ and 5.90 in 42 th, 43th and $37^{\text {th }}$ std. weeks, respectively (Table No.3). The findings of present studies are in conformity with the results of Lanjar et. al., (2002) they reported that the maximum nymphal activity of all grasshopper species was noticed during three weeks after transplanting of crop and adults were maximally active at crop maturity. The study of Bhattacharya et al., (2006), Behera et al., (2007) and Ram, et al., (2014) has similarity to the present investigation.

\section{Green leaf hopper}

The population of green leaf hopper showed positive correlation with relative humidity [M] (0.207518) and negative correlation with maximum temperature and relative humidity (E) $[-0.04332$ and -0.04021]. It showed negative correlation with minimum temperature and rainfall (-0.23824 and 0.16992) during Kharif, 2015 (Table No.2). In Kharif, 2016, its population showed positive correlation with maximum temperature (0.054658). While, negative correlations were registered with relative humidity (E), minimum temperature, relative humidity [M] and rainfall $((-0.54721,-0.28387,-0.102$ and - 
0.26356), respectively (Table No.4). The data of GLH revealed that higher incidence was observed at $44^{\text {th }}, 45^{\text {th, }}, 43^{\text {th }}$ and $42^{\text {th }}$ std. week with 130,122, 115 and 80 per five sweeps, respectively in kharif, 2015 (Table No.1). However, during Kharif, 2016 maximum population were observed at $44^{\text {th }}, 45^{\text {th, }}, 43^{\text {th }}$ and $42^{\text {th }}$ with $120,108,96$ and 75 per five sweeps, respectively (Table No.3).

Bhatnagar (1989) also noted that peak population was observed during the late rainy season from October to November in most areas of India and also reported that hopper thrive well under weekly mean temperature of $26.9{ }^{\circ} \mathrm{C}$, relative humidity of $66.5 \%$, and total weekly rainfall of 0 to $2.8 \mathrm{~mm}$. Pandey et al., (1992); Dale (1994) and Bhatnagar and Saxena (1999) registered as the age of the crop increased, the number of GLH decreased. Bhattacharya et al., (2006); (Anonymous, 2006) and Behera et al., (2007) also gave the similar information. Kissimoto and Dysck, (1976) studied on climatic factors such as temperature, relative humidity, rainfall and mass air movement and their affect on the distribution, development, survival, behaviour, migration reproduction, population dynamics and outbreak of insectpests of rice. These factors usually act in a density independent manner, influencing insects to a greater or lesser extent depending on the situation and the insect species.

\section{Gundhi bug}

The results of correlation studies showed that the population had negative correlation with minimum temperature, relative humidity (E) and rainfall (-0.2804, -0.12972 and -0.2664) in experimental year Kharif, 2015 (Table No.2) whereas, it was negatively correlated with maximum temperature (-0.01049).

The positive correlation of gundhi bug's population was found with relative humidity [M] (0.203846). During Kharif, 2016 its population showed negative correlation with minimum temperature and relative humidity [M] $\quad(-0.26738$ and -0.123), whereas significant negative correlation was found with relative humidity (E) and rainfall (0.58325 and -0.307490). A positive correlation was with maximum temperature (0.143976) (Table 4).

The data presented on the incidence of gundhi bug revealed that the pests was more active at $43^{\text {th }}, 42^{\text {th }}$ and $44^{\text {th }}$ std. week with $20.50,17.90$ and 14.75 per five sweeps, respectively in Kharif, 2015 (Table No.1). During Kharif, 2016 it was higher in $43^{\text {th }}, 42^{\text {th }}$ and $44^{\text {th }}$ std. week with $21.60,17.60$ and 15.25 per five sweeps, respectively (Table No.3).

The findings of present studies are in conformity with results of Rai et al., (1990) they observed peak population of Leptocorisa acuta from $37-42^{\text {th }}$ standard weeks when the crop at milky grain stage. Similar results were also observed by Sugimoto and Nugaliyadde (1995), Nudrin and Artati (2000) and Kissimoto and Dysck (1976). Bhattacharya et al., (2006), Prasad and Prabhu (2010) and Behera et al., (2007) observed it, as important insect-pests

\section{Spider}

There were positive correlations with relative humidity $[\mathrm{M}](0.082223)$ and maximum temperature (0.18292). Correlation of spider were negatively correlated with minimum temperature, relative humidity [E] and rainfall $(-0.0011,-0.0379$ and -0.18255$)$, respectively during kharif, 2015 (Table No.2). The population of spider was found negatively correlated with rainfall $(-0.32283)$ and relative humidity [E] (-0.24235) in kharif, 2016. However, its positive correlation was found with maximum temperature (0.179281), minimum temperature $(0.049984)$ and relative humidity (M) [0.019678] (Table 4). 
Table.1 Incidence of insect-pests o rice crop and their natural during Kharif, 2015

\begin{tabular}{|c|c|c|c|c|c|c|c|c|c|c|}
\hline \multicolumn{7}{|c|}{ Insect } & \multicolumn{4}{|c|}{ Natural Enemies } \\
\hline \multirow[t]{2}{*}{ SW } & \multicolumn{2}{|c|}{ Damage (\%) } & \multicolumn{4}{|c|}{ Avg. No. / 5 Sweep } & \multicolumn{4}{|c|}{ Avg. No. / 5 Sweep } \\
\hline & YSB & $\mathrm{LF}$ & $\mathrm{GH}$ & LF & GLH & GB & Spider & Dgn. Fly & Dmsl. Fly & LBB \\
\hline 34 & 0.20 & 0.00 & 1.23 & 0.00 & 0.00 & 0.00 & 0.00 & 0.00 & 0.00 & 0.00 \\
\hline 35 & 0.26 & 0.00 & 1.86 & 1.95 & 6.50 & 0.00 & 4.25 & 1.50 & 0.00 & 3.80 \\
\hline 36 & 0.90 & 0.00 & 2.90 & 3.96 & 7.75 & 0.00 & 3.25 & 1.15 & 0.00 & 4.25 \\
\hline 37 & 2.25 & 1.00 & 3.66 & 3.10 & 10.50 & 0.00 & 2.75 & 0.75 & 0.00 & 4.50 \\
\hline 38 & 4.60 & 1.20 & 3.90 & 2.90 & 16.00 & 0.00 & 0.80 & 0.75 & 0.00 & 4.60 \\
\hline 39 & 7.20 & 1.45 & 3.96 & 3.93 & 10.25 & 12.10 & 3.85 & 1.50 & 1.75 & 4.75 \\
\hline 40 & 6.50 & 1.76 & 3.85 & 4.83 & 36 & 13.95 & 2.75 & 1.15 & 1.00 & 3.25 \\
\hline 41 & 4.20 & 2.00 & 4.33 & 5.95 & 51 & 14.15 & 2.00 & 0.75 & 0.85 & 2.70 \\
\hline 42 & 3.50 & 2.24 & 3.00 & 3.92 & 80 & 17.90 & 4.95 & 1.50 & 3.35 & 4.75 \\
\hline 43 & 3.40 & 2.87 & 3.45 & 4.96 & 115 & 20.50 & 3.10 & .95 & 2.45 & 5.80 \\
\hline 44 & 2.80 & 3.73 & 4.15 & 6.26 & 130 & 14.75 & 3.65 & 0.20 & 1.85 & 7.85 \\
\hline 45 & 2.50 & 1.17 & 2.66 & 3.63 & 122 & 9.35 & 2.45 & 0.00 & 0.00 & 5.35 \\
\hline 46 & 0.00 & 0.00 & 0.00 & 0.00 & 0.00 & 5.95 & 0.00 & 0.00 & 0.00 & 3.50 \\
\hline 47 & 0.00 & 0.00 & 0.00 & 0.00 & 0.00 & 5.25 & 0.00 & 0.00 & 0.00 & 0.00 \\
\hline 48 & 0.00 & 0.00 & 0.00 & 0.00 & 0.00 & 4.25 & 0.00 & 0.00 & 0.00 & 0.00 \\
\hline 49 & 0.00 & 0.00 & 0.00 & 0.00 & 0.00 & 4.40 & 0.00 & 0.00 & 0.00 & 0.00 \\
\hline
\end{tabular}


Table.2 Correlation of insect-pests and their natural enemies with abiotic factors during Kharif, 2015

\begin{tabular}{|c|c|c|c|c|c|c|}
\hline \multirow{3}{*}{$\begin{array}{l}\text { Serial } \\
\text { No. }\end{array}$} & \multirow[t]{3}{*}{ Insects } & \multicolumn{5}{|c|}{ Weather Parameters } \\
\hline & & \multicolumn{2}{|c|}{ Temperature ${ }^{0} \mathrm{C}$} & \multicolumn{2}{|c|}{ Relative Humidity } & \multirow[t]{2}{*}{ Rainfall (mm) } \\
\hline & & Min. & Max. & $\begin{array}{c}\text { R.H. } \\
\text { Morning }\end{array}$ & $\begin{array}{l}\text { R.H. } \\
\text { Evening }\end{array}$ & \\
\hline 1. & Yellow Stem Borer DH/WE & -0.02103 & 0.17806 & 0.14476 & -0.00442 & -0.05886 \\
\hline 2. & Leaf Folder DL & -0.1665 & 0.044247 & 0.206228 & -0.00673 & -0.08886 \\
\hline 3. & Grass Hopper & -0.00847 & 0.189706 & 0.13911 & 0.046005 & -0.02458 \\
\hline 4. & Leaf Folder & -0.07854 & 0.152932 & 0.104004 & -0.04929 & -0.13619 \\
\hline 5. & Green Leaf Hopper & -0.23824 & -0.04332 & 0.207518 & -0.04021 & -0.16992 \\
\hline 6. & Gundhi Bug & -0.2804 & -0.01049 & 0.203846 & -0.12972 & -0.2664 \\
\hline 7. & Spider & -0.0011 & 0.18292 & 0.082223 & -0.0379 & -0.18255 \\
\hline 8. & Dragon Fly & 0.08751 & 0.241633 & 0.025829 & -0.01078 & -0.13017 \\
\hline 9. & Damsel Fly & -0.13141 & 0.04839 & 0.124541 & -0.07029 & -0.19164 \\
\hline 10. & Lady Bird Beetle & -0.11009 & 0.09475 & 0.188231 & -0.01778 & -0.08698 \\
\hline
\end{tabular}

Significant at $5 \%$ level * Significant at $1 \%$ level **

DL: - Damaged Leaf

DH/WE: - Dead Heart/ White Ear 
Table.3 Incidence of insect-pests o rice crop and their natural during Kharif, 2016

\begin{tabular}{|c|c|c|c|c|c|c|c|c|c|c|}
\hline \multicolumn{7}{|c|}{ Insect } & \multicolumn{4}{|c|}{ Natural Enemies } \\
\hline \multirow[t]{2}{*}{ SW } & \multicolumn{2}{|c|}{ Damage (\%) } & \multicolumn{4}{|c|}{ Avg. No. / 5 Sweep } & \multicolumn{4}{|c|}{ Avg. No. / 5 Sweep } \\
\hline & YSB & $\mathrm{LF}$ & $\mathrm{GH}$ & LF & GLH & GB & Spider & Dgn. Fly & Dmsl. Fly & LBB \\
\hline 34 & 0.00 & 0.00 & 1.12 & 0.00 & 0.00 & 0.00 & 0.00 & 0.00 & 0.00 & 0.00 \\
\hline 35 & 0.30 & 0.00 & 2.24 & 0.00 & 0.00 & 0.00 & 4.85 & 2.2 & 0.95 & 3.5 \\
\hline 36 & 0.88 & 0.22 & 4.23 & 1.72 & 0.00 & 0.00 & 2.95 & 0.95 & 1.2 & 2.10 \\
\hline 37 & 1.42 & 0.60 & 5.90 & 2.14 & 9.6 & 0.00 & 3.15 & 0.4 & 2.9 & 1.55 \\
\hline 38 & 2.66 & 0.95 & 2.25 & 2.16 & 14.4 & 0.00 & 0.5 & 1.26 & 1.18 & 5.65 \\
\hline 39 & 6.90 & 1.35 & 3.35 & 2.22 & 9.5 & 11 & 5.75 & 1.3 & 1.1 & 8.25 \\
\hline 40 & 4.89 & 1.58 & 3.96 & 6.5 & 22 & 13.8 & 3.45 & 1.48 & 0.68 & 7.15 \\
\hline 41 & 3.95 & 1.95 & 4.68 & 10 & 44.44 & 14.9 & 2.15 & 2.25 & 1.1 & 7.65 \\
\hline 42 & 1.65 & 2.74 & 8.52 & 15.5 & 75 & 17.6 & 3.2 & 2.3 & 3.1 & 6.85 \\
\hline 43 & 2.14 & 2.83 & 6.13 & 17.22 & 96 & 21.6 & 3.15 & 2.15 & 1.54 & 6.15 \\
\hline 44 & 2.78 & 3.56 & 5.66 & 19.6 & 120 & 15.25 & 5.15 & 2.4 & 1.15 & 5.1 \\
\hline 45 & 2.18 & 2.02 & 2.98 & 4.55 & 108 & 9.25 & 2.2 & 0 & 0.95 & 3.45 \\
\hline 46 & 0.00 & 0.00 & 0.00 & 0.00 & 0.00 & 6.24 & 0.00 & 0.00 & 0.00 & 0.00 \\
\hline 47 & 0.00 & 0.00 & 0.00 & 0.00 & 0.00 & 5.85 & 0.00 & 0.00 & 0.00 & 0.00 \\
\hline 48 & 0.00 & 0.00 & 0.00 & 0.00 & 0.00 & 3.9 & 0.00 & 0.00 & 0.00 & 0.00 \\
\hline 49 & 0.00 & 0.00 & 0.00 & 0.00 & 0.00 & 2.85 & 0.00 & 0.00 & 0.00 & 0.00 \\
\hline
\end{tabular}


Table.4 Correlation of insect-pests and their natural enemies with abiotic factors during Kharif, 2016

\begin{tabular}{|c|c|c|c|c|c|c|}
\hline \multirow{3}{*}{$\begin{array}{l}\text { Serial } \\
\text { No. }\end{array}$} & \multirow[t]{3}{*}{ Insects } & \multicolumn{5}{|c|}{ Weather Parameters } \\
\hline & & \multicolumn{2}{|c|}{ Temperature ${ }^{0} \mathrm{C}$} & \multicolumn{2}{|c|}{ Relative Humidity } & \multirow[t]{2}{*}{ Rainfall (mm) } \\
\hline & & Min. & Max. & $\begin{array}{c}\text { R.H. } \\
\text { Morning }\end{array}$ & $\begin{array}{c}\text { R.H. } \\
\text { Evening }\end{array}$ & \\
\hline 1. & Yellow Stem Borer DH/WE & 0.06074 & 0.14552 & 0.05000 & -0.16378 & -0.24981 \\
\hline 2. & Leaf Folder DL & -0.21408 & 0.05298 & 0.007635 & -0.43128 & -0.23067 \\
\hline 3. & Grass Hopper & -0.02299 & 0.189256 & -0.08681 & -0.36752 & -0.33879 \\
\hline 4. & Leaf Folder & -0.20125 & 0.119707 & -0.10203 & -0.52282 & -0.25528 \\
\hline 5. & Green Leaf Hopper & -0.28387 & 0.054658 & -0.102 & -0.54721 & -0.26356 \\
\hline 6. & Gundhi Bug & -0.26738 & 0.143976 & -0.123 & -0.58325 & -0.30749 \\
\hline 7. & Spider & 0.049984 & 0.179281 & 0.019678 & -0.24235 & -0.32283 \\
\hline 8. & Dragon Fly & 0.019923 & 0.205636 & -0.03809 & -03133 & -0.28854 \\
\hline 9. & Damsel Fly & 0.06211 & 0.180693 & -0.0285 & -0.20617 & -0.28821 \\
\hline 10. & Lady Bird Beetle & -0.02272 & 0.219237 & -0.00203 & -0.31641 & -0.29884 \\
\hline
\end{tabular}

Significant at $5 \%$ level *

Significant at $1 \%$ level $* *$

DL: - Damaged Leaf DH/WE: - Dead Heart/ White Ear 
Fig.1 Correlation of insect-pests with weather parameters 2015

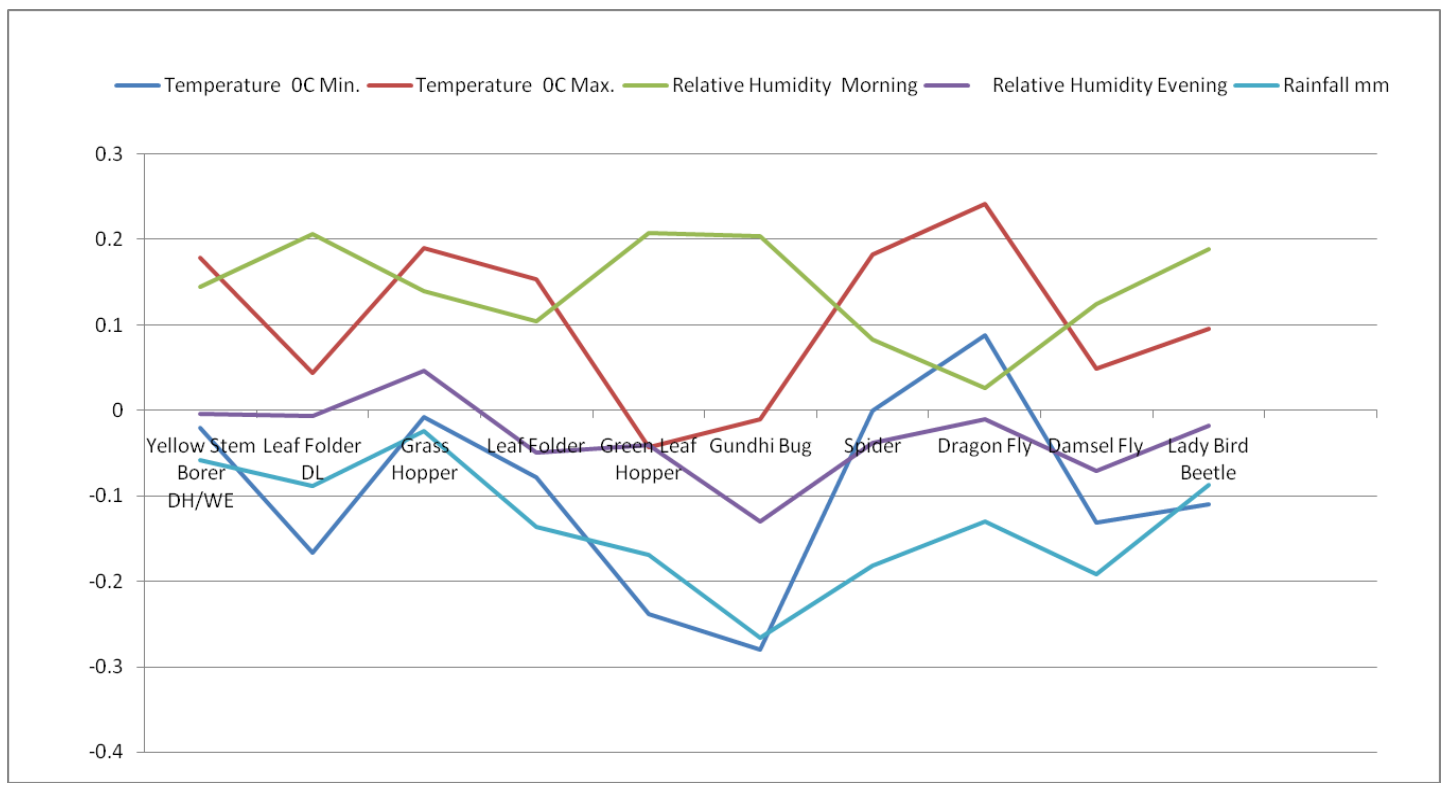

Fig.2 Correlation of insect-pests with weather parameters 2016

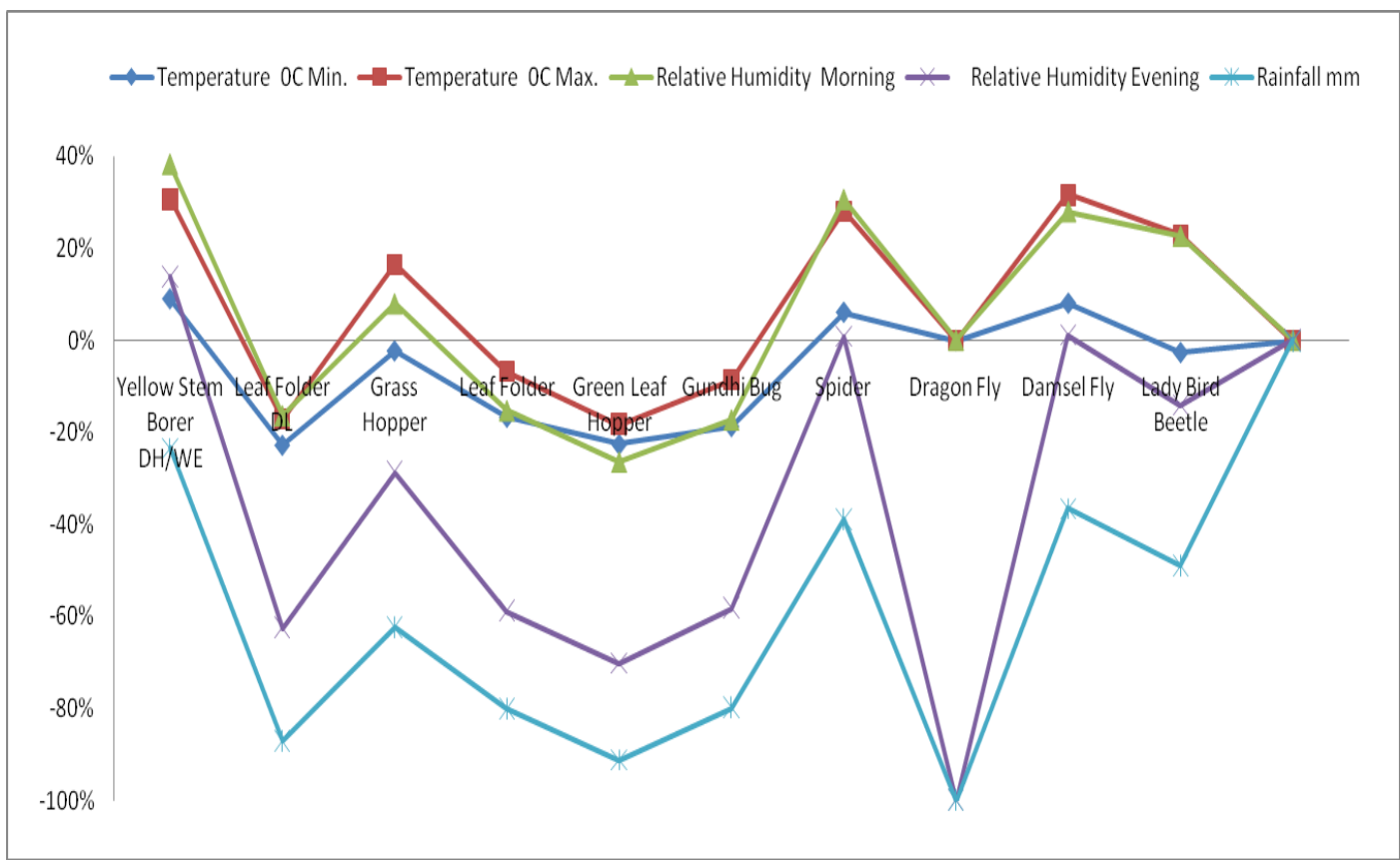

The data of spider revealed that higher incidence was observed at $42^{\text {th }}, 35^{\text {th }}$ and $39^{\text {th }}$ std. week of the crop with $4.95,4.25$ and 3.85 population per five sweeps respectively in kharif, 2015 (Table No.1). However, during Kharif, 2016 higher population were observed at $39^{\text {th }}, 44^{\text {th }}$ and $35^{\text {th }}$ stage of the crop with
$5.75,5.15$ and 4.85 population per five sweeps, respectively (Table No.3). Singh et al., (2005) recorded the highest spider population in month of September and October also which support and make conform the present investigation. Tiwari et al., (2001), Zhang-Yong Jing et al., (2002) 
observed similar results and reported that spiders are the main predators of pests in rice fields. Venkateshalu (1996), Puspakumari and Tiwari (2005), Prasad and Prabhu (2010) and Jadhao and Madhukar (2011) reported that most of the dominant species of spiders appeared throughout the crop growth period. Mohan Reddy (2000) reported peak population of spiders during tillering stage. Chau (1987) reported highest peak of spiders at mean temperature of $23-25^{\circ} \mathrm{C}$ and with relative humidity of 89.94 per cent.

\section{Dragon fly}

During Kharif, 2015, results of correlation studies made on dragon fly population revealed that there were positive correlation with maximum temperature (0.241633), minimum temperature $(0.08751)$ and relative humidity (M) [0.025829]. A negative correlation was found with rainfall $(-0.13017)$ and relative humidity (E) [-0.01078] (Table No.2). In the second experimental year Kharif, 2016, it was evident from the data that the dragon fly's population was positively correlated with minimum temperature (0.019923), and maximum temperature (0.205636). Its population were negatively correlated with relative humidity $(\mathrm{M})$, relative humidity (E) and rainfall $(-0.03809,-0.3133$, and -0.28854 ), respectively (Table No.4).

The data presented on the incidence of dragon fly revealed that, the occurrence was initiated in the month of August and remained upto last week of October in both the experimental year. Kumar, Suneel et al., (2008) supported neck to neck the present findings, they also found the initiation of dragon fly's population in the month of August. Tiwari et al., (2001) and Pasalu (2004) reported the dragonfly is major predator of paddy's pests. Puspakumari and Tiwari (2005) and Kumar, Suneel et. al. (2008) noticed the population of dragon fly occurred maximum in the month of September $1^{\text {st }}$ and to $2^{\text {nd }}$ week of October.

\section{Damsel fly}

The correlation of maximum temperature (0.04839) and relative humidity (M) [0.124541] were found positively nonsignificant with the population of damsel fly. However, its population were negatively correlated with minimum temperature and rainfall (-0.13141 and -0.19164), respectively. A negative correlation also was recorded with relative humidity [E] (-0.07029) during Kharif, 2015 (Table No.2). In second year of experimental observation, the minimum temperature (0.06211) and maximum temperature (0.180693) was positively correlated with damsel fly. Its population were negatively correlated with relative humidity [M] (-0.0285), relative humidity [E] $(-0.20617)$ and rainfall $(-0.28821)$ (Table No.4).

The higher incidence of damsel fly was recorded in the $42^{\text {th }}, 43^{\text {th }}$ and $44^{\text {th }}$ std. week with $3.35,2.45$ and 1.85 population per five sweeps respectively in kharif, 2015 (Table No.1). Whereas, in kharif, 2016 its population was higher in $42^{\text {th }}, 37^{\text {th }}$ and $43^{\text {th }}$ std. week with $3.10,2.90$ and 1.54 population per five sweep, respectively (Table No.3). Tiwari et al., (2001) and Pasalu (2004) also support the present investigation and they recorded damselfly as major predators of paddy pests. Puspakumari and Tiwari (2005), Kumar, Suneel et al., (2008) and Jadhao and Madhukar (2011) recorded damsel fly as important parasitoids of rice insect-pests. They also noticed that the maximum occurrence was seen in the month of September to October.

\section{Lady bird beetle}

The incidence of lady bird beetle on rice crop was positively correlated with maximum temperature $(0.09475)$ and relative humidity [M] (0.188231). Its population was negatively correlated with minimum temperature (- 
$0.11009)$, relative humidity [E] $(-0.01778)$ and rainfall (-0.08698), respectively during Kharif, 2015 (Table No.2). In second of investigation, Kharif, 2016, a positive correlation was registered with maximum temperature (0.219237). The population of lady bird beetle was recorded negatively correlated with minimum temperature ($0.02272)$, relative humidity $[\mathrm{M}](-0.00203)$, rainfall $(-0.29884)$ and relative humidity $[\mathrm{E}](-$ $0.31641)$ (Table No.4).

The incidence of lady bird beetle was started from $35^{\text {th }}$ std. week in both the experimental year kharif, 2015 and 2016 and its last appearance was recorded in the $46^{\text {th }}$ and $45^{\text {th }}$ std. week of kharif, 2015 and 2016, respectively. The peak population was recorded in $44^{\text {th }}$ std. week (7.85 per five sweep), $43^{\text {th }}$ (5.80 per five sweep) and $45^{\text {th }}$ (5.35 per five sweep) in kharif, 2015 (Table No.1). Whereas, in kharif, 2016 it was 8.25 $\left(39^{\text {th }}\right.$ std. week), 7.65 ( $41^{\text {th }}$ std. week) and $7.15\left(40^{\text {th }}\right.$ std. week) per five sweep, in descending order (Table No.3). Sasaji (1968) and Yasumatsu et al., (1975) recorded coccinellids in paddy fields as most important predator. Puspakumari and Tiwari (2005) recorded lady bird beetle as important parasitoids of rice insect-pests from the field. They also noticed that the maximum presence was in the month of September to October. Bhattacharya et al., (2006) and Kumar, Suneel et al., (2008) evaluated that coccinellid beetles were found to be more abundant.

\section{Statistical analysis}

Correlation analysis is drawn between data recorded on pest population and weather parameters. Based on this statistical analyzed data, the results of the investigation have been interpreted and conclusions have been drawn

It can be concluded that, all 5 insects which have been discussed in this paper attacked on the crop. But, out of 6 insects, Yellow Stem Borer, Leaf Folder and Gundhi Bug may be treated as major insect-pests in paddy crop. Natural enemies have a very important role in controlling the insect-pests in rice ecosystem.

\section{Acknowledgement}

The author thanks the Head, Department of Entomology and the Director Research, to provide a piece of land for conducting an experiment in Students Instruction Farm of Chandra Shekhar Azad University of Agriculture and Technology Kanpur -208002 (U.P.) and for the necessary facilities that were made available to carry out the research work.

\section{References}

Alvi, S. M., Ali, M. A., Chaudhary, S. and Iqbal, S. (2003). Population trends and chemical control of rice leaf folder, Cnaphalocrocis medinalis on rice crop. International Journal of Agriculture and Biology 5(4):615-617.

Anonymous (2003). Progress Report (2002), Vol.-2 (Entomology and Pathology). All India Coordinated Rice Improvement project, Directorate of Rice Research, Rajendra Nagar, Hyderabad, A.P, India. pp. 36-39.

Anonymous (2006). Production Oriented Survey 2006, Dir. Rice Res., Hyderabad. pp. 45-93

Ayyanna, T. and Hamidali, M., (1970) Observation on rice stem borer, Scirpophaga incertulas (Walker) attracted to light trap. Andhra Agric. J., 17(1) : 30-32.

Babu, V. R., Veeraprasad, G. S., Ram, T., Subbarao, L. V., Padmavati, G., Bhadana, V. P., Kota, S., Badri, J. and Chaitanya, U. (2014). Rice research in India. National conference on emerging challenges and opportunity in biotic and abiotic stress 
management. Ecobasm . pp 3-4.

Balasubramaniam, G.; Gopalan, M.; Balasubramaniam, M. and Kulandarivelww, R. (1982). Influence of weather factors in the incidence of stem borer in rice. Indian J. Pl. Prot. 9 (1) : 82-87

Bale, J., Masters G, Hodkinson I, Awmack C, Inbezemer TM, Brown VK, Butterfield, Buse, A, Coulson JC, Farrar J, Good GJ, Harrington R, Hartley S, Jones TH, Lindroth L, Press M, Mrnioudis I, Watt A and Whittaker A. 2002. Herbivore in global climate change research: direct effects of rising temperature on insect herbivores. Journal Global Change Biology, 8(5): 1-16.

Bale, J., Masters G, Hodkinson I, Awmack C, Inbezemer TM, Brown VK, Butterfield, Buse, A, Coulson JC, Farrar J, Good GJ, Harrington R, Hartley S, Jones TH, Lindroth L, Press M, Mrnioudis I, Watt A and Whittaker A. 2002. Herbivore in global climate change research: direct effects of rising temperature on insect herbivores. Journal Global Change Biology, 8(5): 1-16

Behra, K.S.; Rao, R.N.; Bhakvastsalama, G. and Rao, K.S. (2007). Arthopod diversity on rice hybrid in irrigated ecosystem. National Symposium on Research Priorities and strategies in Rice Production System for Second Green Revolution, CRRI, Cuttack, Orissa, 20-22 Nov. 2007.

Bhatnagar, A. and Saxena, R.R. (1999). Environmental correlates of population buildup of rice pests through light trap catches. Oryza, 36(3): 241-245p.

Bhatnagar, Y.V. 1989. Occurrence of insect pests on rice crop and studies on the natural enemies of the rice leaf folder Cnaphalocrosis medinalis (Guenee).
Thesis, Master of Science in Agriculture (Entomology). G.B. Pant University $\mathrm{O}$ Agriculture and Technology, Pantanagar. $135 \mathrm{Pp}$.

Bhattacharya, B.; Basit, A. and Saikia, D.K. (2006). Parasitoids and predators of rice insect-pests of Jorhat districts, $J$. Biol. Control. 20 (1): 37-44.

Chau, L. M., (1987). Predators of brown plant hopper Nilaparvata Lugens (Stal) $(\mathrm{BPH})$ in rice fields of the Mekong Delta, Vietnam. Int. Rice Res. Newslett., 12(2) : 31-32.

Chavi, Srivastav, A. and Sharma, K. P. (2015). Population buildup of rice leaf folder Cnaphaocrocis midinalis (Guenee) under arid hill condition of Himachal Pradesh. $4^{\text {th }}$ Congress on Insect Science "Entomology for Sustainable Agriculture" April 16-17 at P.A.U. Ludhiana: pp- 41.

Dale, D. (1994). Insect pests of the rice plant their biology and ecology. In: E.A. Heinrichs (ed). Biology and Management of rice pests. Wiley Eastern Ltd., New Delhi, pp. 111-131.

Denholm, I.; Chapman, J.W.; Denholm, C.; Harrington, R. and Woiwod, I.P. (2001). Insect population dynamics. Institute of Arable Crops. Research Report 2000-2001, pp.-24-27.

Dhaliwal,G.S., Sahi, H.N., Malhi, S.S., Singh, J. and Boparai, B.S. (1984. )Susceptibility of promising Basmati rice varieties to rice leaf folder and whitebacked plant hopper under different level of nitrogen. Indian Journal of Ecology, 11 (2):287-290.

Heinrichs, E.A., Sexena, R.C. and Chelliah, S. 1979. Development and implementation of insect pests management systems for rice in tropical Asia. ASPAC Bulletin 127. Taiwan: Food and fertilizer technology center.

Israel, P. and Rao, (1961). The Incidence of 
Gundhi bug and steps for its control. Proc. Rice Conf., Cuttack, pp. 297-99.

Jadhao, F. and Madhukar (2011). A preliminary study of the predatory natural enemies complex of rice ecosystem in Vidarbha region of Maharashtra, India. Inter. Ref. Res. J. 22(1): 25-26.

Kennedy, G.G. and Storer, N.P. (2000). Life systems of polyphagous arthropod pests in temporally unstable cropping systems. Annual Rev. Entomol, 45, 467-493.

Khan, Z. H. and Ramamurthy, V. V. (2004). Influence of weather factors on the activity of rice leaf folder, Cnaphalocrocis medinalis (Guenee). Annals of Plant Protection Sciences 12(2):267-270.

Khan, Z. H., Gupta, S. L. and Ramamurthy, V. V. (2004). Population dynamics of rice leaf folder (Cnaphalocrocis medinalis) on Pusa Basmati-1 cultivar in relation to weather factors in Delhi. Indian Journal of Entomology 66(4):361-363.

Khush GS. What it will take to feed five billion rice consumers by 2030? Plant Molecular Biology. 2005; 59: 1-6

Kisimoto, R. and Dyck, V.A. (1976). Climate and rice insect. In: climate and rice. IRRI, Los Banos, Philippines, pp. 367391.

Kumar, A., Singh, B., Singh, M. and Jaglan, M. S. (2013). Population dynamics of rice leaf folder Cnaphalocrocis medinalis (Guenee) under agroclimatic conditions of Haryana. Research in Plant Biology 3(4):40-45.

Kumar, J., Rao. N. B. V. C., Singh, V. S. and Parmar, B. S. (2003). Field appraisal of controlled released formulation of phorate against rice leaf folder. International Plant Protection Sciences 11(1): 129-133.

Kumar, S., Khan, M.A., Kumar, A. and
Sharma, K. (2008). Biodiversity of natural enemies in paddy ecosystem and their seasonal dominance. Annals of Plant Protection Sciences 16 (2) : 381-383.

Lakka vijaya Bhasker., 1994, Efficacy of certain insecticides against pest complex of Rice (Oryza sativa Linn.) M. Sc. (Agri.) Thesis, Univ. Agric. Sci., Hyderabad, Andhra Pradesh (India).

Lanjar, A.G., Talpur, M.A., Khushro, R.D. and Qureshi, K.H. (2002). Occurrence and abundance of grasshopper species on rice. Pakistan Journal of Applied Sciences 2(7): 763-763.

Milford, J.R. and Dugdale, G. (1990). Monitoring of rainfall in relation to the control of migrant pests, philosophical Transactions of the Royal Society of London - Series B: Biological Sciences. 328, 689-704.

Mishra, B. K. and Mandal, S. M. A. (2003). Density dependant parasitization of rice leaf folder, Cnaphalocrocis medinalis (Guenee) in the coastal belt of Orissa. Journal of Applied Zoological Researches 14(1):63-64.

Mohan Reddy, L., 2000, Possibilities of utilization of spiders as Bioagents in Rice ecosystem. M. Sc. (Agri.) Thesis, Uni. Agri. Sci., Bangalore, Karnataka (India).

Nudrin, F. and Artati, F. (2000). Insect pests of upland rice in West Sumatra (Indonesia): Its problem and control Technology, 488-492.

Pandey, H.V, Shah, A.H. and Purohit, M.S. (1992). Fluctuation of green leaf hopper population in relation to age of rice crop. Journal of Research, Gujarat Agriculture University, 17, 156-157.

Pasalu, I. C. (2004). Insect-pest management in rice. Training programme in rice production technology sponsored by 
D.R.R. for Co-operators, AICRIP, pp. 1-11.

Pathok, M. D. 1977. Defense of the rice against insect pests. Ann. N.Y. Acad. Sci., 287-295.

Prakash, A. and Rao, J. (2003). Insect-pests of cereals and their management. Pub. by AZRA, CRRI, Cuttack, Orrisa, pp. 167.8

Pushpakumari, A. S. and Tiwari, S. N. (2005). Incidence and population dynamics of rice insect-pests and their natural enemies in Uttranchanl, Pestology XXIX (2): 9-13.

Rai, A.B., Singh, H.J. and Rai, L., 1990, Rice bug (Leptocorisa varicornis Fabr.) appearance to light trap in eastern Uttar Pradesh, India. Oryza, 27: 66-72.

Rajendra Prasad, B.S.; and Prabhu, S.T. (2010). Status of paddy insect-pests and their natural enemies in rainfed eco-systems of Uttarakannad district and management of rice leaf folder.

Ram, M., Sachan, S. K. and Singh, G. (2014). Study on population build up of rice. Rice leaf folder, Cnaphalocrocis medinalis in relation to weather factor. International Journal of Advanced Research 2(10): 75-77.

Sasaji, H., 1968, Coccinellidae collected in the paddy field of the Orient, with description of new species (Coleoptera). 80(11): 644-645.

Singh, A. P., Singh, R. B., Lal, M. N. and
Sharma, R. C. (2013). Effect of planting dates on incidence of insectpests and their predators in Rice field. Indian Journal trends in biosciences 76(6): 818-819.

Singh, J.; Suri, K.S. and Saro, P.S. (2005). Efficacy of granular insecticides against rice stem borer on Basmati rice in Punjab. Indian J. Ent., 67 (3):234-237.

Singh,A.K.,Chandra,N., and Bharti, R. C. (2012).Effects genotypes and planting time on phenology and performance of rice (Oryza sativa L.) Vegetos, 25, 151-156.

Tiwari, V.K., Dubey, O. P. and Tiwari, S.K. (2001). Predatory status of paddy pests in Jabalpur region. Research-onCrops, 2(3): 375-377.

Venkatashalu., 1996, ecological studies on spiders in rice ecosystems with special reference to their role as biocontrol agents. M. Sc. (Agri) Thesis, Uni. Agri. Sci., Bangalore, Karnataka (India).

Yasumatsu, K., Wongsiri, T., Navavichit, S. and Tirawat, C. (1975). Approaches toward an integrated control of rice pests. Plant Protection. Service Technology Bulletin 24: 68.

Zhang-YongJing, Pan-ZhisChong and TongLiJuan (2002). Preliminary studies on the community structure of rice field spiders in Ningbo. Acta-AgricultureZhejiangensis 14(6): 340-343.

\section{How to cite this article:}

Devendra Singh, R. S. Umrao, Kalpana Verma, Akshay Kumar and Vikrant. 2020. Population Dynamics of Major Insect-pests of Rice and their Natural Enemies and its Correlation with Weather Parameters in Central U.P. Int.J.Curr.Microbiol.App.Sci. 9(02): 1517-1531. doi: https://doi.org/10.20546/ijcmas.2020.902.175 